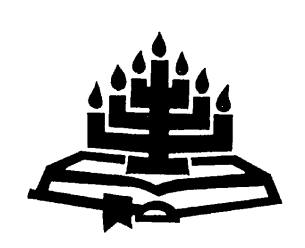

\title{
Gospel and constitutional imperatives: the right to life
}

\author{
S.P. Giles \\ Department of Theology \\ Potchefstroom Campus \\ North-West University \\ POTCHEFSTROOM \\ E-mail: sgiles@telkomsa.net
}

\begin{abstract}
Gospel and constitutional imperatives: the right to life

In the Republic of South Africa, Christians are called to live out gospel imperatives within the legal framework of the Constitution. Ethical issues about the right to life are considered from the perspectives of selected gospel and constitutional imperatives. Gospel imperatives impose themselves as a consequence of Christian discipleship. These are many and diverse, both explicit and implicit. Christian vocation, discipleship, witness and perseverance, are foundational and integral to the praxis of Christian daily living. These facets of Christian life are illustrated by the selected gospel imperatives, "Follow me" (Matt. 4:19 and synoptic parallels), "Love God, and your neighbour as yourself" (Matt. 22:34-40 and synoptic parallels), and "Take up your cross" (Matt. 10:38 and synoptic parallels). The central theoretical argument of this article is driven from a reformed ethical perspective. Gospel imperatives have priority over constitutional imperatives since gospel imperatives are of divine origin and constitutional imperatives of human origin. Acknowledgement of these priorities informs the Christian ethical perspective on the right to life and on abortion.
\end{abstract}

\section{Opsomming}

\section{Evangeliese en grondwetlike imperatiewe: die reg op lewe}

In die Republiek van Suid-Afrika word Christene uitgedaag om evangeliese imperatiewe binne die regskundige raamwerk van die Grondwet uit te leef. Etiese uitvloeisels met betrekking tot die reg op lewe word vanuit die oogpunte van gekose evangeliese en grondwetlike imperatiewe beskou. Evangeliese imperatiewe word gestel as gevolg van Christelike dissipelskap. 
Daar is vele en verskeie, uitdruklike en onuitgesproke imperatiewe. Die Christelike roeping, dissipelskap, getuienis en volharding, is fundameteel en integraal tot die beoefening van die daaglikse bestaan van die Christen. Hierdie onderdele van die Christelike lewe word toegelig deur die gekose evangeliese imperatiewe: "Volg my" (Matt. 14:19 en sinoptiese vergelykings), "bemin God en u naaste soos uself" (Matt. 22:34-40 en sinoptiese vergelykings), en "Neem u kruis op" (Matt. 10:38 en sinoptiese vergelykings). Die sentrale teoretiese betoog van hierdie artikel is, gesien vanuit 'n gereformeerde etiese oogpunt, dat evangeliese imperatiewe voorrang bo grondwetlike imperatiewe geniet, aangesien evangeliese imperatiewe 'n goddelike grondslag het, terwyl grondwetlike imperatiewe 'n menslike oorsprong het. Erkenning van hierdie voorang belig die Christelik-etiese perspektief op die reg tot lewe en aborsie.

\section{Introduction}

From a reformed Christian ethical perspective, the issues of abortion is at best a curtailment and at worst a denial, albeit explicit or implicit, of the Judeao-Christian assertion that God alone creates and sustains life (Gen. 1:26-27); that it is the Lord who gives life and the Lord who takes it away (Job 1:20); and that it is not for anyone to take away human life wilfully at whatever stage (Exod. 20:13).

The right to life, both within the framework of the gospel and the Constitution, is essentially the right to a dignified human life. From a Christian ethical perspective, this right extends from the moment of conception to the moment of death. This is not the case from the South African constitutional perspective that extends the legal right to life from the moment of birth to the moment of death since personhood is deemed to commence only at live birth. The issues of the right to life and abortion are distinct but not separate, vis-à-vis the right to a dignified human life, but are separated in this article for convenience of consideration. Similarly, the selected foundational gospel imperatives "Follow me", "Love God and your neighbour as yourself" and "Take up your cross", are distinct but not separate, vis-à-vis a life of discipleship and the Christian attitude towards the right to a dignified human life and to abortion.

\section{Constitutional imperatives}

\subsection{The secular character of the Constitution}

The Founding Provisions of the Constitution of the Republic of South Africa 1996, and indeed the Constitution in its entirety, while reflect- 
ing implicitly, some moral values held by Christian churches, inter alia dignity, equality, rights, and freedom is not based per se on gospel values or on confessions of Christian churches that publicly profess gospel values. The character of the Constitution expressed in its first chapter is essentially secular, not religious and is described as follows:

The Republic of South Africa is one, sovereign, democratic state founded on the following values:

- Human dignity, the achievement of equality and the advancement of human rights and freedoms.

- Non-racialism and non-sexism.

- Supremacy of the constitution and the rule of law.

- Universal adult suffrage, a national common voters roll, regular elections and a multi-party system of democratic government, to ensure accountability, responsiveness and openness (1 s 1).

Without prejudice to secularity, however, the Constitution tolerates public religious expression that is guaranteed in the Bill of Rights under 2 s 15 Freedom of religion, belief and opinion, and 2 s 31 Cultural, religious and linguistic communities.

In contrast to the constitutional legal framework stands the Christian ethical theoretical framework - the essential content of which is Christ and his gospel. Legal and moral dilemmas arise for the Christian when the imperatives of Christ and his gospel differ from constitutional imperatives with respect to the matter of the right to life and the right to abortion.

\subsection{Constitutional imperatives: formal and material principles}

The formal and material rudimentary principles of constitutional imperatives may be expressed as that the formal rudimentary principle of constitutional imperatives is the supreme law of the Republic. The material rudimentary principle of constitutional imperatives is universal mandatory implementation and compliance. These twin principles govern the consideration of the issues of the right to life and abortion from a constitutional standpoint.

The formal rudimentary principle of the constitutional imperative of the right to life is that everyone has the right to life, and the material rudimentary principle of the constitutional right to life is that life should be respected and protected. This formulation begs the ques- 
tion of the meaning of the term life, and the meaning of the term right. For the purpose of this article a commonly accepted definition of life is used and defined in relevant part in the Dictionary of Law as, "life noun 1. the time when a person is alive" (Collin, 2004). ${ }^{1}$

\subsection{Constitutional right to a dignified human life}

The subject of this article, then, is human life, which is here understood as the "human life of a person", i.e. a living subject with rights in law - natural, and manmade.

In his book entitled, Ethical perspectives on human rights, in the chapter, "A christian theory of human rights", Vorster (2004:94-95) states "One man's duty establishes another man's right". This statement holds truth whether one considers rights as creational rights, that is rights derived from God-given obligations toward creation and humanity, or human rights, namely rights derived from obligations towards creation and humanity solely from the inherent status of a human being per se. Within the reformed ethical framework, rights are understood as God-given creational rights, but are commonly called human rights. This article retains this usage and understanding.

In offering a critique of inter alia the eighteenth-century English jurist John Austin's theory and analysis of law as coercive order, Hart (1961:80) agrees with Austin's point of departure, namely "[...] where there is law, there human conduct is made in some sense non-optional or obligatory". With Austin's formulation, this article understands "right" within the framework of a constitution (written or unwritten) as the sovereign State's binding formulation of nonoptional or obligatory duties towards its citizens and those subject to the Constitution, and the non-optional duties or obligations of citizens and those subject to the Constitution towards the State and one another.

The Constitution's Founding Provisions foresees possible instances of non-compliance with one or more provisions of the Constitution. Interesting is that chapter 2, The Bill of Rights, states: " 1 s 2 This Constitution is the supreme law of the Republic; law or conduct inconsistent with it is invalid, and obligations imposed by it must be fulfilled." In the case of behaviour or conduct inconsistent with the

1 The Collins Dictionary of Law's (2004) definition of person states in relevant part: "person the object of legal rights". 
Constitution which is legally proven, the Constitution provides compliance by coercion under chapter 8 , "Courts and Administration of Justice" (8 s 165 (5)). An order or decision by a court binds all persons to whom and all organs of State to which it applies.

In their most simple and common form, therefore, it may be said that constitutional rights are grounded in obligations and duties, however defined, towards legal personalities national and international, however defined, who are subject to a Constitution which in turn confers rights on these legal personalities. With respect to constitutional rights, s 11, Life; and s 10, Human dignity, considered in this article, the obligation of the Republic of South Africa and legal personalities within the Republic to preserve life and to respect and protect human dignity, confers the right to life and dignity upon legal personalities subject to the Constitution of the Republic of South Africa. It follows that life, per se, is a constitutional imperative.

\subsection{Constitutional imperative of the unqualified right to life}

The Bill of Rights states tersely, "s 11 Everyone has the right to life". Currie and De Waal (2005:281) and Devenish (2005:48) note the textually unqualified nature of this formulation. Although textually unqualified, s 11 along with all other rights in the Bill of Rights is subject to limitation, as Currie and De Waal (2005:281) state: "In South African constitutional law, the right to life may only be limited in terms of the limitation clause [s 36]." Along with s 10 Human dignity, it is noted, however, that although subject to limitation, s 11 Life is entirely non-derogable even in states of emergency. The status of these constitutional rights is designated in s 37 Table of NonDerogable Rights (South Africa, 2006:21). Fedler (1998:15-1) notes:

Unlike other more complex clauses [in the Interim Constitution] $s 9$ [Every person shall have the right to life] and [the Final Constitution] s 11 are deceptively simple. [...] Section 9 and s 11 contain a positive statement, whilst other right to life clauses [in other Constitutions] are often framed negatively. Also where the affirmative version appears in other documents it is often qualified.

The Republic of South Africa's textually unqualified constitutional formulation of the right to life, a formulation referred to repeatedly by the Justices in the case of $S \vee$ Makwanyane and Another 1995, which deals with the abolition of the death penalty, contrasts with numerous constitutionally qualified rights to life. The qualifying formula in common use is, "save in accordance with law" (Malaysia 
Federal Constitution, art. 5 par. 1) or variants thereof. Negative formulations are commonly, "no person", or "a person shall not be", for example, "No person shall be deprived of his life intentionally save in execution of the sentence of a court of law" (Antigua and Barbuda Constitution Order, 1981, art. 4 par 1) (Ibegbu, 2000:47, 60).2

Constitutional qualifications and negative formulations of the right to life apply to the provision of capital punishment. Textual qualifications and negative formulations of the right to life do not specifically occur with respect to the unborn child, zygote, embryo, or foetus, or to the subject of abortion itself.

In Christian Lawyers Association of SA and Others $v$ Minister of Health and Others 1998(4) SA 1113(T), the court arguing from positive law, that is to say manmade law and not natural law, did not dispute that the embryo is a human life. It ruled, however, that it did not logically follow from the embryo's being human life that the embryo or unborn child was entitled to the same protection as everyone else. McCreath quotes Williams (1994:78): "the question is not whether the conceptus is human but whether it should be given the same legal protection as you and me" (Christian Lawyers Association of SA and Others $v$ Minister of Health and Others 1998(4) SA $1113(\mathrm{~T})$ at $1120 \mathrm{I}-\mathrm{J})$. In short, the constitutional unqualified right to life does not extend to the unborn in any way, shape or form.

\subsection{A Christian ethical perspective on Christian Lawyers Association of SA and Others v Minister of Health and Others 1998}

The plaintiff's claim that the constitutional term everyone includes the unborn, was denied solely on grounds of legal positivism, which excluded medical and scientific evidence, religious and philosophical criteria (Christian Lawyers Association of SA and Others $v$ Minister of Health and Others 1998(4) SA 1113(T) at 1118 B-D). Judge McCreath notes that throughout, the Constitution employs the terms everyone and every person interchangeably and it makes reference to $s 38$ Enforcement of rights, which lists such persons who may approach a court (Christian Lawyers Association of SA and Others $v$ Minister of Health and Others 1998(4) SA 1113(T) at $1117 \mathrm{G}-\mathrm{H})$.

2 For a comprehensive list of the constitutional textually qualified right to life, see Ibegbu (2000:46-77). 
The unborn child is not accorded locus standi by $\mathrm{s} 8$. Those listed in this section are already born.

In seeking to define everyone solely on legal grounds to the exclusion of other grounds, McCreath addresses "s 28 Children", and makes the point that had the Constitution intended to include the unborn child in the term everyone, one may reasonably expect to find mention of the unborn child or foetus in this section (Christian Lawyers Association of SA and Others $v$ Minister of Health and Others 1998(4) SA 1113(T) at 1122 B-E). The intention of the framers of legislation is a moot point in South African jurisprudence as instanced in this case. ${ }^{3}$

McCreath also mentions developing jurisprudence regarding the nasciturus rule whereby the unborn is deemed to be born if this would be to the advantage of the unborn, for instance in the case of inheritance (Christian Lawyers Association of SA and Others $v$ Minister of Health and Others 1998(4) SA 1113(T) at 1121 B-D). Within any ethical theoretical framework, secular or religious, the preservation of the life of the unborn is arguably to the advantage of the unborn. 4

\subsection{Right to human dignity: constitutional imperative}

As seen above in chapter 1 , section 1 , the Constitution clearly links human life with human dignity. The formal rudimentary principle of the constitutional imperative of the right to human dignity, however defined, is that everyone has inherent dignity, and the material

3 It should be noted, however, that the issue of the intention of the framers of the Constitution arises three years earlier in S v Makwanyane and Another 1995 with respect to the constitutionality or otherwise of the death sentence.

$\mathrm{He}$ [Mr Bizos] argued that, if the framers of the Constitution had wished to make the death penalty unconstitutional, they would have said so, and that their failure to do so indicated an intention to leave the issue open to be dealt with by Parliament in the ordinary way $(S v$ Makwanyane and Another 1995(3) SA 391(CC) at 404 D-E).

Bizos' argument failed. In this case the lack of the framers' explicit intention to declare the death penalty unconstitutional did not sway the Justices, whereas the lack of the framers specific intention in Christian Lawyers Association and Others $v$ Minister of Health and Others 1998 did sway McCreath. 
rudimentary principle of the constitutional right to life is that human dignity should be respected and protected (1 s 1 ).

This formulation begs the question of the meaning of the term dignity, and the meaning of the term right. The nature and reach of the constitutional imperative of the right to human dignity is inseparable from the constitutional imperative of the right to life. Life and dignity are the two constitutional rights that are to be valued above all other constitutional rights ( $S \vee$ Makwanyane and Another 1995(3) SA $391(\mathrm{CC})$ at $396 \mathrm{~A})$.

\subsection{Human dignity: constitutional character}

Currie and De Waal (2005:273) state:

Though we can be certain of the pivotal importance of human dignity in the Constitution we can be less certain of the meaning of the concept. As is typical of its treatment of important abstractions in the Constitution, the Constitutional Court has not ventured a comprehensive definition of human dignity.

Dignity per se and the innate sense of human dignity demands to be translated into recognisable justice. The uncertain meaning of human dignity is legally problematical, as issues of human dignity must ultimately be something justiciable. The theologian and ethicist Junker-Kenny (2003:59) observes:

A transcendent statement - every human being is accorded human dignity by virtue of his or her moral capability - is transformed into an empirical one, e.g. that suffering and pain are contrary to human dignity.

The issue of abortion from the reformed ethical perspective is likewise contrary to human dignity, or from a pro-choice ethical perspective, compatible with human dignity. In order to come to a legal decision regarding the matter of the right to life and dignity, the courts, and specifically, the Constitutional Court, must always endeavour to work toward a clear understanding on the meaning of the constitutional term, human dignity which it does through its rulings. It is important, therefore, that the Court's definition of this term be as clear as possible, namely all things being equal, otherwise it is very difficult for advocates and opponents of abortion to present their cases. In part, the problem is that human dignity is not a static concept. The judicial understanding of human dignity evolves over time in diverse concrete situations (Vorster, 2007:10). 


\subsection{Dignitas and dignatio: social construct or inherent}

In his article, Barrett makes the distinction between dignity as dignitas, and dignity as dignatio. Barrett argues that within the meaning of the South African Constitution, dignity ought to be understood as dignatio, not dignitas (Barrett, 2005:525). The linguistic distinction between dignitas and dignatio is useful in arriving at a more certain meaning of the abstract concept of human dignity.

Dignatio, as a necessary ethical consequence of human existence is always inherent in all people. Social custom or positive law has simply denied this fact for the benefit of hegemonic groups in societies. The extension of dignitas to all people springs then, from an awakened recognition of dignatio, not its conferral. If dignitas indicates what a particular person has achieved or was born into, dignatio includes the capacity to achieve inherent in everyone. (Barrett, 2005:532.)

Barrett's distinction between dignitas and dignatio is helpful in clarifying the meaning of dignity in terms of the Constitution, and helpful in clarifying the meaning of God-given dignity in terms of Scripture and doctrine. Within the reformed ethical theoretical framework and any given secular ethical theoretical framework, dignatio may be held to be inherent and dignitas relative. This distinction between inherent and relative dignity is, however, from a reformed ethical perspective moot, for dignitas and dignatio are not always necessarily distinct, as the following critique suggests.

\subsection{Dignitas and dignatio: a reformed perspective}

From a Christian anthropological perspective the following questions arise: Are dignitas and dignatio as defined by Barrett, always necessarily distinct? How easy in practice is it to distinguish between the two concepts of human dignity? Is dignitas, as Barrett suggests, only conferred by society, or is it possible for a person to hold dignitas without reference to society's appraisal? Is it not the case that a person whose socially conferred status is low, for example, he/she may be afflicted by material poverty, poor physical health, poor mental health, illiteracy, lack of formal education, poor housing, may present a shining example of nature's own gentleman? When one encounters such a person, may one not ask if dignitas, like dignatio is innate? Christian anthropology, which considers the person to be the bearer of God's image, answers that this is indeed the case. Reformed Christian anthropology regards dignitas and dignatio as two sides of the same coin of God-given human dignity. God-given 
dignity is an indivisible quality that inheres in each and every living person from conception to the date of birth to the date of death.

In sum, whilst affirming that dignatio and dignitas are inseparably constituent of human dignity per se, this article will speak of the constitutional imperative of the right to human dignity, and the Christian understanding of God-given human dignity in terms of Barrett's useful definition of dignatio and insisting that the right to a dignified human life extends to the unborn.

\section{Gospel imperatives}

\subsection{Gospel imperatives as divine imperatives}

The reformed theologian Brunner(1937:57) notes:

The Reformation as a whole is simply one long protest against moral levity, one long struggle for the reality of the Good. That was the whole point of the struggle for sola fide in the fight against a 'righteousness of works', for moralism, with its legalism and self-righteousness is at all times the worst enemy of true morality.

Brunner (1937:58) defines the good according to the truth of the Bible: "Only that which God wills is good; and thus [...] we are to will what God wills because he wills it." And, one may add, by God's grace, actively respond to God's will, is the good. The Christian may arguably perceive in the issues of the right to life and abortion an attitude of moral levity if courts decide issues before them on legal grounds alone to the exclusion of scientific, medical, religious or philosophical grounds as in Christian Lawyers and Others v Minister of Health and Others 1998.

In the light of Brunner's dictum, "Only that which God wills is good", responses to the issues of the right to life and abortion are not only divine imperatives in God's eyes, they also become divine imperatives in the eyes of Christ's disciples, and the collective of Christ's disciples, his church and thereby determinative of the Christian approach of the right to life and to abortion.

\subsection{Gospel imperatives: formal and material principles}

The formal rudimentary principle of gospel imperatives is the risen Christ and God-given faith in this living person who is God's ultimate revelation of the good. The material rudimentary principle of gospel imperatives is obedience to the person of the risen Christ revealed 
in the Word of God, which is something living and active (Heb. 4:12). These principles are applied to the chosen foundational gospel imperatives of following Christ, loving God and one's neighbour as oneself, and taking up one's cross with respect to the Christian attitude towards the right to life that extends to the unborn and issue of abortion.

The formal rudimentary principle of the gospel imperative "Follow me", is Christ's call to discipleship, and the material rudimentary principle is, by God's grace, obedience to Christ's call. This formulation requires scriptural exegesis of Matthew 4:19-20 and the synoptic parallels.

"And He said to them, 'Follow me, and I will make you fishers of men.' Immediately they left their nets and followed Him." (Matt. 4:1920; Throckmorton, 1979:16.) The imperative to follow Jesus Christ is discussed in two distinct but related aspects, namely the call to office and the call to discipleship. Both come into play when considering ethical and moral dilemmas. The call to office plays a decisive role in instructing and forming the call to discipleship.

\section{3 "Follow me"}

The proclamation of the kingdom of heaven (Matt. 4:17) precedes Jesus' imperative call, "Follow me", and Peter and Andrew's imperative response. Jesus' call to discipleship and the response to the call to discipleship are imperative. Matthew's rendering of Jesus' imperative, "Come after me" (come, deute), is hortatory (Donahue \& Harrington, 2002:74). Jesus' command itself incites those who hear to respond. This form of speech underlines the authoritative nature of Jesus' imperative call to discipleship. The unhesitating nature of the response to Jesus' call 'suggests the power of Jesus' call and his attractiveness" (Donahue \& Harrington, 2002:74). Peter and Andrew's response to Jesus' call is a continuation of God's affirmation of Jesus and God's mission confided to Jesus.

In Matt. 4:18-22 the one whom the Father called in Matt. 3:17 now calls others who will advance his mission. Jesus' call to leave profession and family was radical, the sort of demand that only the most radical teacher would make. The text provides Matthew's community with several examples of servant leadership and radical discipleship. (Keener, 1999:149.)

Keener points out the high personal cost of following Jesus in giving priority to the proclamation of the kingdom of heaven. The transition from fisherman to itinerant disciple entailed an economic loss of 
livelihood and family security, and an associated reduction in social status and social dignity (Keener, 1999:151-155).

Jesus' call to Andrew and Peter is not only one of discipleship, but to the particular office of apostle, an office of instructing, as Calvin (1949a:242) calls it. Christ does not call all disciples to apostleship and the hardship entailed in leadership exercised through, with and in Christ. "There are some whom the Lord is satisfied with having in his flock and his Church, while he assigns to others their own station." (Calvin, 1949a:243.) Jesus' initial call to Peter and Andrew is to the task of forming a community of believers. "For God's rule does not operate in a void - it implies a people living under it. It involves the formation of a community." (Hunter, 1949:31.) Be the call to that of apostle or to that of discipleship alone, it is important to note the imperative response to the imperative call. Hunter (1949:32) observes that the word straightaway (immediately) is used 41 times by Mark, often as a connecting link, but it lends "an air of breathlessness to his story which is the story of Jesus proclamation of the Kingdom of Heaven and its priority over all else". The same air of breathlessness ought to characterise those who follow Jesus today, particularly his servants of the Word.

Discipleship therefore derives directly from Christ's call and is not dependent on any other authority within the community.

The role of Apostle and of the Twelve is a distinct office or ministry within the community. Discipleship, however, is wider than the office of Apostle or the Twelve. Jesus' call to discipleship precedes his call to apostleship. ... The two essential elements of the call to discipleship are being with Jesus and doing the things of Jesus. (Donahue \& Harrington, 2002:31.)

Donahue and Harrington (2002:31) enumerate six characteristics of Jesus' call to discipleship in Mark's Gospel: the call to discipleship is Jesus' initiative; Peter, Andrew and others were engaged in ordinary occupations; the call is unambiguous, it is a clear summon; the call is to share in the missionary task of the One calling; the response to the call is immediate and spontaneous; the response to the call is not private but communal as the one joins others who have responded. In every age, Christ's disciples do not choose Jesus; prior formal learning in theology and philosophy is not a prerequisite; they are invited to respond to Christ's call and thereafter discover its implications in following Him. The call is not to promote slavishly the teachings of Jesus as related in the gospel, rather it is a call to 
collaboration and communion with Jesus and his disciples. Jesus' call to discipleship is a divine imperative, a call to each and every member of Christ's church to become "fishers of men" and to leave everything for Christ and his gospel. In casting aside everything else and following Jesus, disciples will, in responding to Jesus' imperative to love God and their neighbours, discover the true meaning and implications of following Jesus. This is of importance to the focus of this article, namely the right to life, abortion and the Christian attitude towards these.

\title{
3.4 "Love God, and your neighbour as yourself"
}

The formal rudimentary principle of the gospel imperative "Love

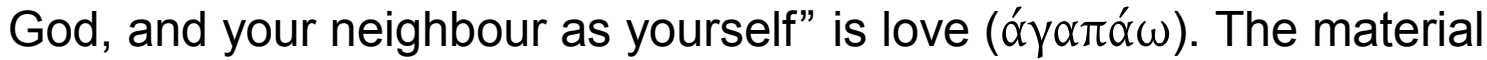
rudimentary principle is, by God's grace, to love God with all one's mind and heart and one's neighbour as oneself. This formulation requires scriptural exegesis of Matthew 22:34-40 and the synoptic parallels.

\begin{abstract}
When the Pharisees heard that he had silenced the Sadducees, they gathered together, and one of them, a lawyer, asked him a question to test him. 'Teacher, which commandment in the law is the greatest?' He said to him, 'You shall love the Lord your God with all your heart, and with all your soul, and with all your mind'. This is the greatest and first commandment. And the second is like it: 'You shall love your neighbour as yourself'. On these two commandments hang all the law and the prophets. (Matt. 22:34-40.)
\end{abstract}

The lawyer's question about the greatest commandment and Jesus' affirmation of the priority of love above other commandments of duty or obedience, was part of an ongoing debate among teachers of the law as to whether duty took precedence over love or vice versa, with respect to the law (Donahue \& Harrington, 2002:530-531). The love that Jesus speaks of does not remain an abstract, but is given meaning as an active ingredient of discipleship. The primacy of love "is also clearly the fundamental ground upon which the ethical teaching of the New Testament church is built" (Hagner, 1995:647). Paul writes to the church in Rome that love is the fulfilment of the law (Rom. 13:8-10), and to the church in Galatia, that love is the summary of the whole law (Gal. 5:14). The Johannine community receives Jesus' new commandment

[...] love one another. Just as I have loved you, you also should love one another. By this everyone will know that you are my disciples, if you have love for one another. (John 13:34-35.) 
James, the leader of the church in Jerusalem, holds that loving one's neighbour as oneself is the supreme law in one's dealing with one's fellow human beings (Jas. 2:8; Donahue \& Harrington 2002: 531). On the priority of love, Calvin writes, "Above all, clothe yourselves with love, which binds everything together in perfect harmony." (Col. 3:14; Calvin, 1949b:61.)

In conformity with Christ and his gospel, the primacy of love remains the formal principle of the church's ethical teaching. The question as to why love is central to the Christian ethic, is answered by Jesus at the end of his exchange with the lawyer, "On these two commandments hang all the law and the prophets" (Matt. 22:40). Calvin understands by this that Jesus does not intend to reduce all other commandments to love of God and neighbour, "but because all that is anywhere taught (in Scripture) as to the manner of living a holy and righteous life must be referred to these two leading points" (Calvin, 1949b:63).

Christ's response to the lawyer sets a lofty ethical benchmark. The imperative of loving God with all one's heart, soul, mind and strength demands that the whole person loves God and the imperative of loving one's neighbour as oneself is based on the understanding that a person cares for himself enough to promote and protect his own interests. "The [ethical] challenge is to show the same kind of love to others." (Donahue \& Harrington, 2002:355.) The accompanying parable of the good Samaritan in Luke 10:25-37, understands neighbour and love of neighbour not generally, that is restricted to one's friends, acquaintances and co-religionists, but universally. "The general truth conveyed is, that the greatest stranger is our neighbour, because God has bound all men together for the purpose of assisting each other." (Calvin, 1949b:61.) In short, the JudeaoChristian imperative to love the Lord God with all one's heart, with all one's soul, with all one's mind and with all one's strength is universal - universal in embracing the whole of one's being, and universal in loving each and every fellow human being, whether seen and unseen, known or unknown, born or unborn.

Universal dimensions of loving God and neighbour, therefore, have implications for the issues of the right to life and abortion, since universal love embraces the unborn child, which implies the duty and responsibility of promoting and protecting the right to life of the individual child in utero. On the principle of the universality of the imperative, "Love God, and your neighbour as yourself", the life of the individual unborn child cannot be taken away at will, even when the complex situation of the mother and/or the family would indicate 
abortion as a possible solution among other solutions to, for example a given pressing social problem. From a Christian ethical perspective, giving exclusive priority to one's own life over the life of another effectively hinders Christ's disciple from fulfilling the imperative to take up one's cross and from bearing witness to Christ and his gospel, even at some cost to oneself.

\section{5 "Take up your cross"}

The formal rudimentary principle of the gospel imperative, "Take up your cross", is commitment to Christ. The material rudimentary principle is, by God's grace, to persevere in one's commitment to Christ. "[...] and whoever does not take up his cross and follow me is not worthy of me" (Matt. 10:38).

Only John 19:17 relates that Jesus carried his own cross to his execution. In the synoptic Gospels, Simon of Cyrene is pressed into carrying Jesus' cross to Golgotha (Matt. 19:17; Mark 15:21; Luke 23:26). The difference matters not, for here the point is not that the condemned carries his instrument of execution to the place of execution, but that his life is forfeit. When one becomes a follower of Jesus, your life is forfeit possibly even to physical death (Keener, 1999:331). Keener further points out that in the Pauline tradition the disciple's willingness to die for Christ's sake becomes death to self and to his right to make selfish choices: "Put to death, therefore, whatever in you is earthly: fornication, impurity, passion, evil desire, and greed (which is idolatry)." (Col. 3:5; 3:3; Rom. 6:3-4; Keener, 1999:331, footnote 51.) This is a lifelong process: "Luke believes that the Christian life is dying daily to self [Lk 9:23],) much as Paul does in 1 Cor 15:31: 'Every day I die'." (Tinsley, 1965:101.)

Calvin (1949a:472) states that one cannot be a disciple without carrying the cross of suffering:

Let us remember this condition, that Christ subjects all his disciples to the cross. Yet let us also bear in mind this consolation, that in bearing the cross, we are the companions of Christ.

Discipleship and the cross are intimately linked, but the disciple always bears the cross of Christ in his company. With Christ carrying the cross, it becomes easier and lighter than it would be otherwise, much after the fashion of Christ's yoke and burden (Matt. 11:30). 
As one must love God with all one's heart, soul, mind and strength, Christ demands of his disciples commitment to the same degree, that is total commitment of one's whole self to Christ and his gospel. But then why should Jesus Christ, God incarnate, demand any less of those whom He calls to discipleship? The imperative of taking up one's cross day after day continually actualises the imperatives "Follow me" and "Love God and your neighbour as yourself". This is arguably nowhere more true than with respect to extending the right to life by protection of vulnerable unborn human life.

\section{Conclusion}

Flowing from the secular character of the Constitution is the legal question of the right to life and dignity of the unborn. Implicit in the issue of the right to life of the unborn are several questions: At what stage of biological development is the unborn considered an unborn child? At what stage from the point of conception and throughout its biological development, zygote, embryo, foetus, until the date of birth, ought the unborn to be accorded natural status and hence legal personality, and therefore the right to life? On these points Slabbert (1997:91) comments:

Die vraag na die regsdimensies of regstatus van die menslike embrio en fetus, een van die mees kontroversiële regsvrae ooit, is van belang ten einde die regstatus en regsbelange van hierdie entiteite af te baken.

The Constitutional recognition or denial of the natural status of the unborn determines the unborn's constitutional right to life (s 11) and dignity (s 10). Consequently, constitutional recognition or denial of the unborn's right to the fullness of life and dignity, and protection of that life in its fullness before the law, is affected accordingly.

Currently, the unborn child in the RSA is denied natural status under the Constitution. 5 Touching on the legal status of the foetus, McCreath states: "I proceed to a consideration of the provisions of the Constitution itself. There is no express provision affording the foetus (or embryo) legal personality or protection" (Christian Lawyers Association of SA and Others $v$ Minister of Health and Others 1998(4) SA 1113(T) at $1121 \mathrm{G}-\mathrm{H})$.

5 The Oxford Dictionary of Law defines unborn [as] "a child still in its mother's body and not yet born" (Martin, 2003:2). 
This constitutional position, vis-à-vis the legal status of the unborn, is in contrast with the reformed Christian ethical position regarding the status of the unborn as imago Dei (Gen. 1:26-27) and as a gift of God (Gen. 30:2, 22; 49:25; Deut. 7:13; 1 Sam. 1:5; Job 1:21; Ps. $127: 3 ; 139: 13$; Is. $44: 2$, 24; John 1:3) and therefore, belongs to God (Exod. 13:2, 12; 34:19; Job 1:21; Ps. 71:6; John 1:3). This presents a moral dilemma for the reformed tradition that extends the right to life to the unborn. In the reformed churches, human beings are held to be God's work, created in God's image and likeness, and confessed as such (Belgic Confession, 14, 1999:46; cf. also Second Helvetic Confession, 1999a:46). The unborn child according to Calvin has the same status as a born child. It does not become imago Dei later in its development. Calvin holds the unborn child is ensouled at the moment of conception (Sermons on Job 12; Jones, 2004:146). This, in contrast to Aquinas's discussion of different souls in the timing of ensoulments of unborn male and female children (Aquinas, 1965; Summa, 90-102:3-15). Douma (1996:127) denies that the unborn baby is not a mere collection of cells or a lump of tissue in its first stages of life. From a reformed ethical perspective the unborn at all stages of biological development is held to be an unborn child created in the image of God.

This natural status of the unborn child as imago Dei clearly conflicts with the constitutional position that confers natural status only at the date of birth. The Christian assertion that the unborn child has natural status implies legal status for the unborn child under the Constitution, and here under consideration, particularly with respect to abortion. This presents a Christian moral conflict with regard to the right to life, for, in order to be endowed with legal status, the Constitution must recognise someone as a natural person. Under the Constitution, the unborn child - zygote, embryo or foetus - is not a natural person, as McCreath observes above. Clearly, the constitutional perspective and the reformed perspective on the status of the unborn have implications regarding the approach to abortion. The approach of the former, within the parameters of the Constitution, is a utilitarian respect of the mother's wishes and a denial of the unborn child's right to life. The approach of the latter, within the parameters of Scripture and the Constitution, is respect for the Godgiven life of the unborn child. The unborn child's God-given human dignity demands nothing less.

A fundamental distinction between the constitutional framework and the reformed Christian ethical theoretical framework is that according to the latter, there is no essential bioethical distinction between 
prenatal and postnatal stages of life. Rheeder (2002:479) highlights this when he writes:

Twee sake staan dus vas. Allereers: daar is 'n mens-in-ontwikkeling en nie 'n ontwikkeling-na-'n-mens nie. Vervolgens: daar is nie 'n ontwikkelde mens nie, asof daar in die embrionale ontwikkeling verder niks meer gebeur nie.

In the reformed Christian tradition, therefore, the unborn child, from the point of conception, is held to be endowed with natural status and dignity derived from its God-given status as imago Dei. This status the unborn shares with constitutional natural persons, and as such it is imperative that the church and those forming the church extend to the unborn child the love that one has for God and oneself, and this, even at great cost of forgoing the constitutional option of abortion.

\section{List of references}

AQUINAS. 1965. Man's actual production as far as his soul is concerned. (In Batten, R.J. St. Thomas Aquinas Summa theologiæ - Latin texts and English translation, introductions, notes, appendices and glossaries. Vol. 34(1a:90-102). Cambridge: Blackfriars. p. 3-15.)

BARRETT, J. 2005. Dignatio and the human body. South African journal on human rights, 21(4):532-546.

BELGIC CONFESSION. 1999. (In Beeke, J.R. \& Ferguson, S.B., eds. Reformed confessions harmonized. Grand Rapids: Baker. p. 2-244.)

BRUNNER, E. 1937. The divine imperative - a study in Christian ethics. London: Butterworth.

CALVIN. 1949a. Commentary on a harmony of the evangelists Matthew, Mark, and Luke. Vol. 1. Trans. by W. Pringle. Grand Rapids: Eerdmans.

CALVIN. 1949b. Commentary on a harmony of the evangelists Matthew, Mark, and Luke. Vol. 3. Trans. by W. Pringle. Grand Rapids: Eerdmans.

COLLIN. P.H. 2004. Dictionary of Law. 2nd ed. London: Bloomsbury.

CURRIE, I. \& DE WAAL, J. 2005. The Bill of Rights handbook. 5th ed. Cape Town: Juta.

DE FREITAS, S.A. 2006. Transcending "life" in the biblical protection of the unborn: perspectives towards a jurisprudential anti-abortion apologetic. Journal for Christian scholarship, Special no. 2:169-193.

DEVENISH, G.E. 2005. The South African Constitution. Durban: LexisNexis Butterworths.

DONAHUE, J.R., SJ. \& HARRINGTON, D.J., SJ. 2002. The Gospel of Mark. Collegeville: The Liturgical Press. (Sacra pagina series, vol. 2.)

DOUMA, J. 1996. The Ten Commandments - manual for the Christian life. Phillipsburg: P \& R.

FEDLER, J. 1998. Constitutional Law of South Africa. Kenwyn: Juta. (15-1 - 1510.)

HAGNER, D.A. 1995. World biblical commentary. Vol. 33B: Matthew 14-28. Dallas: Word Books. 
HART, H.L.A. 1961. The concept of law. Oxford: Clarendon.

HUNTER, A.M. 1949. St. Mark. London: SCM.

IBEGBU, J.I. 2000. Rights of the unborn child in international law - towards a convention. Vol. 1. Lewiston: The Edward Mellen Press.

JONES, D.A. 2004. The soul of the embryo - an enquiry into the status of the human embryo in the Christian tradition. London: Continuum.

JUNKER-KENNY, M. 2003. Does dignity need a theological foundation. (In Ammitch-Quinn, R., Junker-Kerry [sic], M. \& Tamez, E., eds. The discourse of human dignity. Vol. 2: Concilium. London: SCM. p. 57-66.)

KEENER, C.S. 1999. A commentary on the Gospel of Matthew. Grand Rapids: Eerdmans.

MARTIN, E.A. 2003. Dictionary of Law. 5th ed. Oxford: Oxford University Press.

RHEEDER, A.L. 2002. Die menslike embrio - 'n reg op lewe? 'n Voorlopige teologiese boordeling. In die Skriflig, 36(3):475-498.

SECOND HELVETIC CONFESSION. 1999. (In Beeke, J.R. \& Ferguson, S.B., eds. Reformed confessions harmonized. Grand Rapids: Baker. p. 2-244.)

SLABBERT. M.N. 1997. Enkele regsaspekte rondom aborsie. (In Durand, M.C., red. Verrigtinge van die simposium oor aborsie. Gezina: Die Stigting van Etiese Medisyne. p. 91-96.)

SOUTH AFRICA. 2006. The Constitution of the Republic of South Africa. 3rd ed. Landsdown: Juta.

THROCKMORTON, B.H., Jr. 1979. Gospel parallels: a synopsis of the first three Gospels - with alternative readings from manuscripts and noncanonical parallels. Bangalore: Theological Publications in India.

TINSLEY, E.J. 1965. The Gospel according to Luke. Cambridge: Cambridge University Press.

VORSTER, J.M. 2004. Ethical perspectives on human rights. Potchefstroom: Potchefstroom Theological Publications.

VORSTER, N. 2007. Restoring human dignity in South Africa: Christian anthropology in a new dispensation. Potchefstroom: Potchefstroom Theological Publications.

WILLIAMS, G. 1994. The foetus and the right to life. Cambridge law journal, 35(1):71-80.

\section{List of cases}

Christian Lawyers Association of SA and Others $v$ Minister of Health and Others 1998(4) SA 1113(T)

S v Makwanyane \& Another 1995 (3) SA 391 (CC)

\section{Key concepts:}

abortion

Constitution

gospel

human dignity

imperative, Constitution

imperative, gospel

right to life 


\section{Kernbegrippe:}

aborsie

evangelie

grondwet

imperatief, Grondwet

imperatief, evangelies

menslike waardigheid

reg tot lewe 